\title{
EFFICACY OF PEGINTERFERON ALPHA-2A AND RIBAVIRIN COMBINATION THERAPY IN TREATMENT-NAIVE ESTONIAN PATIENTS WITH CHRONIC HEPATITIS C
}

\author{
Vadim Brjalin ${ }^{1,2}$, Riina Salupere ${ }^{2}$, Tatjana Tallo ${ }^{3,4}$, Tatiana Kuznetsova ${ }^{3}$, Ljudmilla Priimägi ${ }^{3}$, Valentina Tefanova ${ }^{3}$ \\ ${ }^{1}$ Department of Internal Medicine, West-Tallinn Central Hospital, Tallinn, Estonia \\ ${ }^{2}$ Department of Internal Medicine, University of Tartu, Estonia \\ ${ }^{3}$ Department of Virology, National Institute for Health Development, Tallinn, Estonia \\ ${ }^{4}$ Department of Preparedness, Swedish Institute for Communicable Disease Control, Stockholm, Sweden
}

\begin{abstract}
SUMMARY
Aim: The aim of the study was to assess the efficacy of pegylated interferon (Peg-IFN) $a$-2a and ribavirin (RBV) combination therapy in treatmentnaive patients with chronic hepatitis $C$ in Estonia.

Methods: Out of 121 outpatients with chronic hepatitis C (73 males, 48 females, aged 19-63) enrolled in the study, 76 were infected with HCV genotype $1 \mathrm{~b}$ and 45 with genotype $3 \mathrm{a}$. At baseline, the viral load in $75.2 \%$ of patients was higher than $600,000 \mathrm{IU} / \mathrm{mL}$. Histologically, $88.4 \%$ of patients had fibrosis score F0-2. Patients received $180 \mu \mathrm{g}$ of Peg-IFN a-2a weekly plus daily ribavirin 1,000 or 1,200 $\mathrm{mg}$, depending on body weight, in HCV genotype $1 \mathrm{~b}$, or $800 \mathrm{mg} /$ day in genotype 3a infection.

Results: The overall sustained virologic response (SVR) rate in our study was $60.3 \%$, being statistically lower for patients with HCV genotype $1 \mathrm{~b}$ as compared to patients with genotype $3 \mathrm{a}(46.1 \% \mathrm{vs.} 84.4 \%, p<0.05)$. The non-response and relapse rates were significantly higher in patients infected with $\mathrm{HCV}$ genotype $1 \mathrm{~b}$ compared with patients infected with genotype $3 a$ (19.7\% vs. $2.2 \%, p=0.01$; and $17.1 \%$ vs. $4.4 \%, p=0.04$; respectively).

The SVR rate was higher in patients younger than 40 years compared with older patients $(76.4 \%$ vs. $47.0 \%, p<0.01)$, regardless of the genotype. Thirteen patients infected with HCV genotype $1 \mathrm{~b}$ required dose reduction of PegIFN and/or RBV because of adverse side effects. Nine of them achieved SVR.

Conclusion: HCV genotype and age younger than 40 years predetermined SVR rate in treatment-naive Estonian patients with chronic hepatitis $\mathrm{C}$ treated with Peg-IFN a-2a plus ribavirin.
\end{abstract}

Key words: chronic hepatitis C, genotypes, pegylated interferon, ribavirin, sustained virologic response, viral load

Address for correspondence: V. Brjalin, Department of Internal Medicine, West-Tallinn Central Hospital, Paldiski road 68, Tallinn, 10617, Estonia. E-mail: vbrjalin@gmail.com

\section{INTRODUCTION}

Hepatitis C virus (HCV) is a leading cause of chronic liver disease, end-stage cirrhosis, and liver cancer worldwide (1). As a result, long-term care and liver transplantation are needed, which consequently imposes a significant burden on the health care system.

The estimated global prevalence of $\mathrm{HCV}$ infection is around $3 \%$, corresponding to 170 million infected people $(2,3)$. In different European countries the prevalence of HCV ranges between 0.1 and $5 \%(4,5)$. According to an educated guess, up to $1 \%$ of $1.34 \mathrm{mln}$ of Estonian inhabitants are infected with $\mathrm{HCV}$, and this virus was reported as the main aetiological agent for chronic hepatitis in Estonian patients $(6,7)$.

Several risk factors for $\mathrm{HCV}$ infection are well established. In Estonia, HCV transmission via medical interventions including transfusion of blood and blood products and surgery has declined significantly since the mid 1990s. From 1996 up today, injection drug use (IDU) has become the most common mode of infection $(6,7)$. However, for $50-60 \%$ of all notified $\mathrm{HCV}$ cases the source of infection remains unknown.

There is no vaccine and no post-exposure prophylaxis for HCV. The current standard of care for patients with chronic hepatitis $\mathrm{C}(\mathrm{CHC})$ is based on combination treatment with pegylated interferon-alpha plus ribavirin (Peg-IFN $\alpha / \mathrm{RBV}$ ) administered for 24 or 48 weeks depending on the viral genotype (8). The primary goal of antiviral treatment for chronic hepatitis $\mathrm{C}$ is a long-lasting $\mathrm{HCV}$ eradication.

In Estonia, treatment principles of chronic hepatitis $\mathrm{C}$ were introduced in 2001. Nowadays, the enrolment of patients and their further treatment are conducted according to the National Guidelines on the combined treatment of $\mathrm{CHC}$ with Peg-IFNa/ RBV, which were approved by the Estonian Society of Gastroenterology and the Estonian Society for Infectious Diseases in 2006 and updated in 2007 and 2010. Annually, around 400 patients with $\mathrm{CHC}$ receive combined antiviral treatment. 
The criterion for evaluation of therapy efficacy is sustained virological response (SVR), defined as serum HCV RNA undetectable by a sensitive molecular assay at week 24 after the end of therapy (9). When patients achieve SVR the risk of virological relapse is very low (10)

Both viral and host factors appear to be important in the virological response to combination therapy $(11,12)$.

The HCV has been classified into 6 major genotypes and a number of subtypes (13). HCV genotypes have a geographically distinct distribution (14). In Estonia, subtypes $1 \mathrm{~b}$ and $3 \mathrm{a}$ are predominating alike in other East European countries (15).

The HCV genotype has emerged as an important factor both in predicting SVR and in determining the duration of antiviral therapy with genotype 1 infections having the lowest response rates and requiring the longest therapy (16-19). High viral load, male gender, advanced fibrosis/cirrhosis and older age are the factors associated with a less favourable response to antiviral therapy $(20,21)$.

The aim of our study was to evaluate the efficacy of peginterferon alpha-2a and ribavirin therapy depending on HCV genotype, baseline viral load, fibrosis stage, age and gender in treatmentnaive Estonian patients with chronic hepatitis $\mathrm{C}$.

To our knowledge, this is the first systematic study to assess the factors predicting the outcome of Peg-IFN $\alpha / \mathrm{RBV}$ combination treatment in patients with chronic hepatitis $\mathrm{C}$ in clinical practice in Estonia.

\section{MATERIALS AND METHODS}

\section{Patients}

From February 2005 to September 2010, a total of 121 treatment-naive patients with chronic hepatitis $\mathrm{C}$ visiting the Outpatient Clinic of West-Tallinn Central Hospital were enrolled in our prospective clinical study.

The diagnosis of $\mathrm{CHC}$ was based on presence of anti-HCV antibodies in the sera, detection of serum HCV RNA, histologically verified fibrosis stage and clinical follow-up.

The exclusion criteria were age $<18$ and $>63$ years, chronic alcohol intake, decompensated cirrhosis, current injection drug use and depression. All patients were serologically negative for antibodies to human immunodeficiency virus and to hepatitis B virus surface antigen.

Patients were systematically questioned about risk factors, including past blood transfusion or surgical procedures, injection drug use, at-risk occupation, and history of hepatitis in the family. They were also asked about possible sources and transmission routes of infection as tattoos and acupuncture.

Patients enrolment and their further treatment were conducted according to the National Guidelines on treatment of $\mathrm{CHC}$.

Complete blood counts, ALT, AST, bilirubin, TSH, and autoantibodies were measured before the start of therapy and during follow-up.

Serum HCV RNA levels before therapy and at week 12 and 48, and 24 weeks after treatment were analysed by a quantitative PCR assay (COBAS ${ }^{\circledR}$ AmpliPrep/COBAS ${ }^{\circledR}$ TaqMan HCV test with a lower limit of detection of $15 \mathrm{IU} / \mathrm{mL}$, the linear range of the assay being from 43 to 69,000,000 IU/mL; Roche, Branchburg).
The HCV genotypes were determined by the hybridization technique using a VERSANT HCV genotype assay (LiPA), Bayer Health-Care LLC, Tarrytown, NY.

HCV RNA and the genotyping assays were performed in the Laboratory of HIV Diagnostics at West-Tallinn Central Hospital.

All patients underwent an ultrasound guided liver biopsy. The range of fibrosis (F) was classified according to the Metavir scoring system from F0 to F4 (cirrhosis).

All patients, depending on the genotype, were administered 48 or 24 weeks standard therapy. The Peg-IFN $\alpha$-2a (Pegasys, F. Hoffmann La Roche Ltd, Basel, Switzerland) was administered at a dosage of $180 \mu \mathrm{g} /$ week. The RBV (Copegus, F. Hoffmann La Roche Ltd, Basel, Switzerland) was given per os at a dosage of $1,200 \mathrm{mg} /$ day or $1,000 \mathrm{mg}$ /day depending on body weight (above or below $75 \mathrm{~kg}$ ), for patients infected with genotype $1 \mathrm{~b}$; and at a dosage of $800 \mathrm{mg} /$ day, regardless of the body weight, in patients infected with genotype $3 \mathrm{a}$.

Written informed consent was obtained from all patients prior to the study for use of clinical data and serum samples.

\section{Statistical Analysis}

For statistical analysis, the $\chi^{2}$ test, Fisher's exact test and Student's t-test were used.

Multivariate logistic-regression analysis was used to explore the baseline factors that could be used for prediction of SVR.

\section{RESULTS}

The baseline characteristics of the studied patients are shown in Table 1.

From 121 eligible patients $73(60.3 \%)$ were males with a mean age of $38.3 \pm 11.8$ years and $48(39.7 \%)$ were females with a mean age of $42.2 \pm 11.7$ years. No statistically significant difference was found between the ages of two genders $(p=0.07)$.

In total, $76(62.8 \%)$ of patients were infected with HCV genotype $1 \mathrm{~b}$ and $45(37.2 \%)$ with genotype $3 \mathrm{a}$ (Table 1$)$. The mean age of patients infected with genotype $1 \mathrm{~b}$ was significantly higher than the mean age of those infected with genotype 3a (42.7 vs. 35.1 years; $p<0.01$ ).

At baseline, the viral load of $75.2 \%$ of all patients was higher than $600,000 \mathrm{IU} / \mathrm{mL}$, with no statistically significant difference between the genotypes (76.4\% with genotype $1 \mathrm{~b}$ vs. $73.3 \%$ with genotype $3 \mathrm{a}, \mathrm{p}=0.894)$.

Of all patients who underwent a pretreatment liver biopsy, the grade of liver fibrosis was F0-1 in 91 patients (75.2\%); and F2 in 16 patients $(13.2 \%)$; 14 patients $(11.6 \%)$ had advanced fibrosis (F3-4) (Table 1).

Medical interventions (52.6\%) followed by past IDU (13.2\%) and blood donation $(7.9 \%)$ were the more prevalent risk factors for patients infected with subtype $1 \mathrm{~b}$. For patients infected with subtype 3 a the most prevalent risk factors were past IDU (40\%), medical interventions $(22.2 \%)$ and sexual contacts (15.6\%). Other risk factors as at-risk occupation, tattoo and piercing were of less importance. For $18.2 \%$ of the patients risk factors were not identified.

According to treatment response, the patients were divided into three groups: 1) patients who achieved SVR, 2) non-responders 
Table1. Baseline characteristics of the study patients

\begin{tabular}{|c|c|c|c|}
\hline Characteristic & $\begin{array}{c}\text { Genotype } 1 \\
n=76\end{array}$ & $\begin{array}{c}\text { Genotype } 3 \\
n=45\end{array}$ & $\begin{array}{c}\text { All patients } \\
n=121\end{array}$ \\
\hline \multicolumn{4}{|l|}{ Sex, $(n, \%)$} \\
\hline Male & $44(57.9)$ & $29(64.4)$ & $73(60.3)$ \\
\hline Female & $32(42.1)$ & $16(35.6)$ & 48 (39.7) \\
\hline Age (years), range & $19-63$ & $21-55$ & $19-63$ \\
\hline Mean $\pm S D$ & $42.7 \pm 11.7$ & $35.1 \pm 11.5$ & $39.9 \pm 11.7$ \\
\hline \multicolumn{4}{|l|}{ Viral load, (n, \%) } \\
\hline$\leq 0.6 \mathrm{mln} \mathrm{IU} / \mathrm{mL}$ & $18(23.6)$ & $12(26.7)$ & $30(24.8)$ \\
\hline$>0.6-2.5 \mathrm{mln} \mathrm{IU} / \mathrm{mL}$ & $38(50.0)$ & $23(51.1)$ & $61(50.4)$ \\
\hline$>2.5-4.0 \mathrm{mln} \mathrm{IU} / \mathrm{mL}$ & $10(13.2)$ & $6(13.3)$ & $16(13.2)$ \\
\hline$>4.0 \mathrm{mln} \mathrm{IU/mL}$ & $10(13.2)$ & $4(8.9)$ & $14(11.6)$ \\
\hline \multicolumn{4}{|l|}{ Fibrosis stage $(\mathrm{n}, \%)^{*}$} \\
\hline F0-F1 & $58(76.3)$ & $33(73.3)$ & $91(75.2)$ \\
\hline F2 & $7(9.2)$ & $9(20.0)$ & $16(13.2)$ \\
\hline F3 & $3(4.0)$ & $2(4.5)$ & $5(4.2)$ \\
\hline F4 & $8(10.5)$ & $1(2.2)$ & $9(7.4)$ \\
\hline ALT, IU/mL, range & $16-586$ & $20-505$ & $16-586$ \\
\hline Mean $\pm S D$ & $103.7 \pm 88.2$ & $143.6 \pm 109.8$ & $118.4 \pm 95.5$ \\
\hline \multicolumn{4}{|l|}{ Mode of infection $(n, \%)$} \\
\hline Medical manipulations ${ }^{a}$ & $40(52.6)$ & $10(22.2)$ & $50(41.3)$ \\
\hline Injection drug use & $10(13.2)$ & $18(40.0)$ & $28(23.1)$ \\
\hline Sexual exposure & $2(2.6)$ & $7(15.6)$ & $9(7.4)$ \\
\hline Other & $8(10.5)$ & $4(8.9)$ & $12(10.0)$ \\
\hline Unknown & $16(21.1)$ & $6(13.3)$ & $22(18.2)$ \\
\hline
\end{tabular}

*Liver histology was graded according to the Metavir scoring system: F0, no fibrosis; F1, portal fibrosis without septa; F2, portal fibrosis with rare septa; F3, numerous septa without cirrhosis; and F4, cirrhosis.

ALT, alanine aminotransferase; HCV, hepatitis $C$ virus; SD, standard deviation. ${ }^{a}$ Medical manipulations: blood transfusion and/or surgery.

(NR), i.e. patients in whom sera HCV RNA levels remained stable during treatment and 3) relapsers (RL), i.e. patients who sero-reverted to HCV RNA during follow-up. Treatment outcomes are shown in Table 2 .

A total of 73 of the 121 patients (60.3\%) achieved SVR after combination therapy with Peg-IFN $\alpha /$ RBV. The SVR rate was statistically lower for patients infected with genotype $1 \mathrm{~b}$ compared with patients infected with genotype $3 \mathrm{a}(46.1 \%$ vs. $84.4 \%$, $\mathrm{p}=0.00004)$.
Overall non-response and relapse rates were 13.2\% (16/121) and $12.4 \%(15 / 121)$, respectively, being significantly higher for patients infected with genotype $1 \mathrm{~b}$ compared with patients infected with genotype $3 \mathrm{a}(19.7 \%$ vs. $2.2 \%, \mathrm{p}=0.01$ and $17.1 \%$ vs. $4.4 \%, \mathrm{p}=0.04)$, respectively.

Seventeen patients out of $121(14.0 \%)$ discontinued treatment: 8 patients because of side effects and 9 patients were lost to follow-up.

The mean baseline viral load was $6.02 \pm 0.57 \log \mathrm{IU} / \mathrm{mL}$ which did not differ significantly between patients with SVR $(5.94 \pm 0.56 \mathrm{log}$ $\mathrm{IU} / \mathrm{mL})$ and those with non-SVR $(6.14 \pm 0.54 \log \mathrm{IU} / \mathrm{mL}, \mathrm{p}=0.058)$.

Out of all patients, $73.3 \%$ (22/30) with pretreatment levels of viremia below $600,000 \mathrm{IU} / \mathrm{mL}$ achieved SVR versus $57.4 \%$ (35/61) with HCV RNA levels above $600,000 \mathrm{IU} / \mathrm{mL}$, although the difference was not significant $(\mathrm{p}=0.25)$. Nor was there found significant correlation of SVR with baseline levels of HCV RNA depending on the genotype $(\mathrm{P}=0.33)$.

Overall, SVR rate was higher for patients younger 40 years compared with older patients $(76.4 \%$ vs. $47.0 \%, \mathrm{p}=0.001416)$ regardless of the genotype.

There was found no difference between the genders in relation to SVR rate $(54.8 \%$ males vs. $68.7 \%$ females; $\mathrm{p}=0.13)$.

The SVR rate in patients with the fibrosis score $0-1$ and in patients with the fibrosis score $2-3$ was $64.8 \%$ (59/91) and $66.7 \%$ (14/21), respectively, the difference being statistically insignificant ( $p=0.09$ ). All 9 patients with cirrhosis (F4) failed to achieve SVR, among them 8 patients were infected with genotype $1 \mathrm{~b}$ and one patient was infected with genotype $3 \mathrm{a}$.

Multivariate logistic regression analysis showed that only two factors increased the odds of achieving SVR independently and significantly: HCV genotype 3 [odds ratio (OR), 6.359; confidence interval $(\mathrm{CI}), 2.525-16.017, \mathrm{p}<0.0001]$ and patient age 40 years or less (OR 0.274; CI $0.125-0.603, p=0.0014$ ), with no correlation with pretreatment viral load, fibrosis score or male sex.

Out of all patients, 96.7\% (117/121) experienced one or more of the following side effects: fatigue $-90.1 \%$, neutropenia $79.3 \%$, thrombocytopenia $-59.5 \%$, anaemia $-34.7 \%$, depression $-24.8 \%$, alopecia $-19.8 \%$ and myalgia $-11.5 \%$.

Thirteen of the 76 patients (17.1\%) infected with HCV genotype $1 \mathrm{~b}$ required dose reduction of PegIFN and/or ribavirin because of adverse events. Neutropenia below 0.75 x 109/1 and haemoglobin level $<100 \mathrm{~g} / \mathrm{l}$ were the main reasons for dose reduction of PegIFN or ribavirin. Six patients who required dose reduction achieved SVR. Three patients who required dose reduction but discontinued treatment prematurely at week 44, also achieved SVR. Three patients were recognized as non-responders, and one patient stopped treatment because of intolerance of therapy.

Table 2. Responses to combination therapy with peginterferon and ribavirin of study patients

\begin{tabular}{|l|c|c|c|c|}
\hline $\begin{array}{l}\text { Treatment } \\
\text { outcomes }\end{array}$ & $\begin{array}{c}\text { Genotype } 1 \mathrm{~b} \\
\mathrm{n}=76\end{array}$ & $\begin{array}{c}\text { Genotype 3a } \\
\mathrm{n}=45\end{array}$ & $\begin{array}{c}\text { All patients } \\
\mathrm{n}=121\end{array}$ & $p_{\text {-value* }}$ \\
\hline SVR, $\mathrm{n}(\%)$ & $35(46.1)$ & $38(84.4)$ & $73(60.3)$ & 0.0004 \\
\hline Non-response, $\mathrm{n}(\%)$ & $15(19.7)$ & $1(2.2)$ & $16(13.2)$ & 0.01 \\
\hline Relapse, $\mathrm{n}(\%)$ & $13(17.1)$ & $2(4.4)$ & $15(12.4)$ & 0.04 \\
\hline Discontinued treatment, $\mathrm{n}(\%)$ & $13(17.1)$ & $4(9.0)$ & $17(14.1)$ & 0.282 \\
\hline
\end{tabular}

*Differences between patients infected with genotype $1 \mathrm{~b}$ and genotype $3 \mathrm{a}$ 


\section{DISCUSSION}

Nowadays combination therapy with pegylated interferon plus ribavirin is the treatment of choice for chronic hepatitis $\mathrm{C}$.

Our study was designed to evaluate the efficacy of Peg-IFN $\alpha-2 \mathrm{a}$ and ribavirin combination therapy in Estonian treatmentnaive patients infected with $\mathrm{HCV}$ genotypes $1 \mathrm{~b}$ and $3 \mathrm{a}$, and to analyse the factors that might affect treatment outcome.

For assessment of treatment efficacy, we used SVR which is defined as undetectable serum HCV RNA within 24 weeks after the end of therapy.

Response to PegIFN/RBV-based antiviral therapy is influenced by different factors related to virus or host characteristics (22-24). Of the viral factors, HCV genotype has been identified as the most important baseline predictor for treatment response (25). For patients infected with genotypes 2 or 3, combination therapy is highly effective, and a 24-week course of peginterferon plus ribavirin results in SVR for 70 to $80 \%$ of patients (26-30). For patients infected with genotype 1 and 4 and especially with subtype $1 \mathrm{~b}$, which is the predominant subtype in Estonia, a full 48 -week course of treatment leads to SVR rate for about $50 \%$ of patients (31-34).

In our study we obtained similar data. Thus, the rate of SVR for patients infected with subtype $1 \mathrm{~b}$ was twice as low as that for patients infected with genotype $3 \mathrm{a}(46.1 \%$ vs. $84.4 \%)$.

None-response is defined as failure to clear serum HCV RNA within 24 weeks after the start of therapy. Patients with recurrence of serum HCV RNA during the period between the end of treatment and 6 months thereafter are defined as relapsers. Relapse usually occurs in $10-15 \%$ of treated patients $(35,36)$. The overall rates of non-response and relapse in our study were $13.2 \%$ and $12.4 \%$, respectively, being significantly higher for patients with HCV genotype $1 \mathrm{~b}$ (19.7\% and $17.1 \%$, respectively).

Measurement of the viral load before and during therapy is useful in monitoring of treatment efficacy. Patients with high baseline viral loads are less likely to achieve sustained virologic response compared with those with low viral loads, regardless of the genotype $(37,38)$. We observed some difference in SVR rates between patients with pretreatment levels of viremia below $600,000 \mathrm{IU} / \mathrm{mL}$ and those with levels above $600,000 \mathrm{IU} / \mathrm{mL}(73 \%$ vs. $57 \%$ ), but this difference did not reach significance.

In patients with chronic hepatitis $\mathrm{C}$, advanced liver fibrosis and cirrhosis are associated with lower (up to $40 \%$ ) rates of SVR to standard combined therapy $(39,40)$. In our study, $65 \%$ of the patients with fibrosis score $0-1$ and fibrosis stages $2-3$ achieved SVR, while none of the patients with compensated cirrhosis (F4) achieved it. However, the small number $(9 / 121)$ of these patients did not allow to make any relevant conclusions.

In general, patient-related factors negatively influencing therapy outcome are male gender $(41,42)$ and older age (43). Our data demonstrated that SVR rate was higher for female than for male patients ( $69 \%$ vs. $55 \%$ ), although the difference was not statistically significant.

The average age of patients infected with $\mathrm{HCV}$ is increasing, being currently $45-54$ years, which is markedly different from the age 25-39 years in the past (44). In previous prospective studies on the efficacy of PegIFN and RBV combination therapy, younger age was significantly correlated with SVR and patients younger than $40-45$ years showed the best response rate $(21,23,28,45)$.
In our study, half out of all treated patients were older than 40 years. The overall rates of SVR were significantly higher for patients younger than 40 years compared with older patients $(\mathrm{p}<0.01)$.

In general, approximately $75 \%$ of treated patients experienced one or more systematic side effects, while $10-16 \%$ of patients treated with peginterferon and ribavirin had to discontinue the therapy due to adverse effects (46-49). In our study, 96.7\% of patients experienced one or more side effects among which the most prevalent were fatigue, hematologic abnormalities and depression. However, adverse events were generally mild and the treatment discontinuation rate was therefore low.

Although so far several factors have been identified as predictors of treatment outcome, none of them is reliable for individualized prediction when used independently. Based on the results of our study, we made an attempt to find out which pretreatment factors might be associated with the response to combined therapy in Estonian patients infected with genotypes $1 \mathrm{~b}$ and $3 \mathrm{a}$. We demonstrated that only virus genotype (3a vs. 1b) and age younger than 40 years significantly predetermined SVR rate, while viral load and advanced liver fibrosis stage did not reach statistical significance among treatment-naive Estonian patients with chronic hepatitis $\mathrm{C}$ treated with Peg-IFN $\alpha$-2a plus ribavirin.

A limitation of this study might be the selection bias arising from the National Guidelines for treatment of chronic hepatitis C, which does not recommend to treat all patients older than 63 years. The mean age of patients in our study was 40 , and owing to the natural course of $\mathrm{HCV}$ it was unlikely to expect high number of patients with F3 or F4 stages at this age. Another limitation is that the number of patients selected for the study was smaller than in most previous treatment studies in which several hundreds of patients or more were enrolled (26). However, the characteristics of patients in the present study were comparable to those reported previously and represent a true picture of $\mathrm{CHC}$ patients enrolled for treatment in Estonia.

Thus, the results of our single-centre study are generally consistent with the results of similar studies evaluating the efficacy of Peg IFN $\alpha-2$ a plus ribavirin in treatment-naive patients with $\mathrm{CHC}$. Yet there is a clear need for getting deeper insights into the host and virus nature in order to optimize the possibilities of curing chronic hepatitis $\mathrm{C}$ infection in Estonia.

\section{Acknowledgement}

The authors would like to thank Sofia Sidorova, senior laboratory specialist from the Department of Virology, National Institute for Health Development, for her valuable technical assistance; Margarita Malish, nurse, West-Tallinn Central Hospital, for assistance in management of HCV outpatients; Monika Tuuling, senior product manager, Estonian Roche, for treatment coordination.

\section{Conflict of interest}

None declared

\section{Sponsorship and adherence to ethical recommendations}

This study was supported by grant No.7650 of the Estonian Science Foundation and partially funded by Estonian Roche.

The study was approved by the Tallinn Medical Research Ethics Committee. 


\section{REFERENCES}

1. Alter MJ. Epidemiology of hepatitis C virus infection. World J Gastroenterol. 2007 May 7;13(17):2436-41.

2. Shepard CW, Finelli L, Alter MJ. Global epidemiology of hepatitis C virus infection. Lancet Infect Dis. 2005 Sep;5(9):558-67.

3. Baldo V, Baldovin T, Trivello R, Floreani A. Epidemiology of HCV infection. Curr Pharm Des. 2008;14(17):1646-54.

4. Esteban JI, Sauleda S, Quer J. The changing epidemiology of hepatitis $\mathrm{C}$ virus infection in Europe. J Hepatol. 2008 Jan;48(1):148-62.

5. Mühlberger N, Schwarzer R, Lettmeier B, Sroczynski G, Zeuzem S, Siebert U. HCV-related burden of disease in Europe: a systematic assessment of incidence, prevalence, morbidity, and mortality. BMC Public Health. 2009 Jan 22;9:34.

6. Tefanova V, Tallo T, Kutsar K, Priimgi L. Urgent action needed to stop spread of hepatitis B and C in Estonian drug users. Euro Surveill. 2006 Jan 26;11(1):E060126.3.

7. Priimägi L, Tefanova V, Tallo T. Emerging viral hepatitis B and C in Estonia. In: Berencsi G, Khan AS, Haloužka J, editors. Emerging biological threat. Amsterdam: IOS Press; 2005. p. 20-5.

8. Ghany MG, Strader DB, Thomas DL, Seeff LB; American Association for the Study of Liver Diseases. Diagnosis, management, and treatment of hepatitis C: an update. Hepatology. 2009 Apr;49(4):1335-74.

9. National Institutes of Health. National Institutes of Health Consensus Development Conference Statement: Management of hepatitis C: 2002 - June 10-12, 2002. Hepatology. 2002 Nov;36(5 Suppl 1):S3-20.

10. Maylin S, Martinot-Peignoux M, Moucari R, Boyer N, Ripault MP, Cazals-Hatem D, et al. Eradication of hepatitis $\mathrm{C}$ virus in patients successfully treated for chronic hepatitis C. Gastroenterology. 2008 Sep;135(3):821-9.

11. Berg T, Sarrazin C, Herrmann E, Hinrichsen H, Gerlach T, Zachoval R, et al. Prediction of treatment outcome in patients with chronic hepatitis $\mathrm{C}$ : significance of baseline parameters and viral dynamics during therapy. Hepatology. 2003 Mar;37(3):600-9.

12. Hoofnagle JH, Wahed AS, Brown RS Jr, Howell CD, Belle SH; Virahep-C Study Group. Early changes in hepatitis C virus (HCV) levels in response to peginterferon and ribavirin treatment in patients with chronic $\mathrm{HCV}$ genotype 1 infection. J Infect Dis. 2009 Apr 15;199(8):1112-20.

13. Simmonds P, Bukh J, Combet C, Deléage G, Enomoto N, Feinstone S, et al. Consensus proposals for a unified system of nomenclature of hepatitis C virus genotypes. Hepatology. 2005 Oct;42(4):962-73.

14. Smith DB, Simmonds P. Review: molecular epidemiology of hepatitis C virus. J Gastroenterol Hepatol. 1997 Jul;12(7):522-7.

15. Tallo T, Norder H, Tefanova V, Krispin T, Schmidt J, Ilmoja M, et al. Genetic characterization of hepatitis $\mathrm{C}$ virus strains in Estonia: fluctuations in the predominating subtype with time. J Med Virol. 2007 Apr;79(4):37482.

16. Fried MW, Shiffman ML, Reddy KR, Smith C, Marinos G, Gonçales FL $\mathrm{Jr}$, et al. Peginterferon alfa-2a plus ribavirin for chronic hepatitis $\mathrm{C}$ virus infection. N Engl J Med. 2002 Sep 26;347(13):975-82.

17. Zeuzem S. Heterogeneous virologic response rates to interferon-based therapy in patients with chronic hepatitis C: who responds less well? Ann Intern Med. 2004 Mar 2;140(5):370-81

18. Feld JJ, Hoofnagle JH. Mechanism of action of interferon and ribavirin in treatment of hepatitis C. Nature. 2005 Aug 18;436(7053):967-72.

19. Jacobson IM, Davis GL, El-Serag H, Negro F, Trépo C. Prevalence and challenges of liver diseases in patients with chronic hepatitis $\mathrm{C}$ virus infection. Clin Gastroenterol Hepatol. 2010 Nov;8(11):924-33; quiz e117.

20. Almasio PL, Cottone C, D'Angelo F. Pegylated interferon therapy in chronic hepatitis $\mathrm{C}$ : lights and shadows of an innovative treatment. Dig Liver Dis. 2007 Sep;39 Suppl 1:S88-95.

21. Yamada G, Iino S, Okuno T, Omata M, Kiyosawa K, Kumada H, et al. Virological response in patients with hepatitis $\mathrm{C}$ virus genotype $1 \mathrm{~b}$ and a high viral load: impact of peginterferon-alpha-2a plus ribavirin dose reductions and host-related factors. Clin Drug Investig. 2008;28(1):9-16. Erratum in: Clin Drug Investig. 2008;28(4):210.

22. Strader DB, Wright T, Thomas DL, Seeff LB; American Association for the Study of Liver Diseases. Diagnosis, management, and treatment of hepatitis C. Hepatology. 2004 Apr;39(4):1147-71. Erratum in: Hepatology. 2004 Jul;40(1):269.

23. Foster GR, Fried MW, Hadziyannis SJ, Messinger D, Freivogel K, Weiland $\mathrm{O}$. Prediction of sustained virological response in chronic hepatitis $\mathrm{C}$ patients treated with peginterferon alfa-2a (40KD) and ribavirin. Scand J Gastroenterol. 2007 Feb;42(2):247-55
24. Saludes V, Bracho MA, Valero O, Ardèvol M, Planas R, GonzálezCandelas F, et al. Baseline prediction of combination therapy outcome in hepatitis $\mathrm{C}$ virus $1 \mathrm{~b}$ infected patients by discriminant analysis using viral and host factors. PLoS One. 2010 Nov 30;5(11):e14132.

25. Hofmann WP, Zeuzem S, Sarrazin C. Hepatitis C virus-related resistance mechanisms to interferon alpha-based antiviral therapy. J Clin Virol. 2005 Feb;32(2):86-91.

26. Hadziyannis SJ, Sette H Jr, Morgan TR, Balan V, Diago M, Marcellin P, et al.; PEGASYS International Study Group. Peginterferon-alpha2a and ribavirin combination therapy in chronic hepatitis $\mathrm{C}$ : a randomized study of treatment duration and ribavirin dose. Ann Intern Med. 2004 Mar 2;140(5):346-55.

27. von Wagner M, Huber M, Berg T, Hinrichsen H, Rasenack J, Heintges T, et al. Peginterferon-alpha-2a (40KD) and ribavirin for 16 or 24 weeks in patients with genotype 2 or 3 chronic hepatitis C. Gastroenterology. 2005 Aug;129(2):522-7.

28. Shiffman ML, Suter F, Bacon BR, Nelson D, Harley H, Solá R, et al.; ACCELERATE Investigators. Peginterferon alfa-2a and ribavirin for 16 or 24 weeks in HCV genotype 2 or 3. N Engl J Med. 2007 Jul 12;357(2):124-34.

29. François C, Castelain S, Duverlie G, Capron D, Nguyen-Khac E. Optimizing the treatment of chronic viral hepatitis C. Expert Rev Gastroenterol Hepatol. 2009 Dec;3(6):607-13.

30. Dalgard O, Bjoro K, Ring-Larsen H, Verbaan H. In patients with HCV genotype 2 or 3 infection and RVR 14 weeks treatment is noninferior to 24 weeks. Pooled analysis of two Scandinavian trials. Eur J Gastroenterol Hepatol. 2010 May;22(5):552-6.

31. Manns MP, McHutchison JG, Gordon SC, Rustgi VK, Shiffman M, Reindollar R, et al. Peginterferon alfa-2b plus ribavirin compared with interferon alfa-2b plus ribavirin for initial treatment of chronic hepatitis C: a randomised trial. Lancet. 2001 Sep 22;358(9286):958-65.

32. Lindh M, Alestig E, Arnholm B, Eilard A, Hellstrand K, Lagging M, et al. Response prediction and treatment tailoring for chronic hepatitis $\mathrm{C}$ virus genotype 1 infection. J Clin Microbiol. 2007 Aug;45(8):2439-45.

33. Yu JW, Wang GQ, Sun LJ, Li XG, Li SC. Predictive value of rapid virological response and early virological response on sustained virological response in $\mathrm{HCV}$ patients treated with pegylated interferon alpha-2a and ribavirin. J Gastroenterol Hepatol. 2007 Jun;22(6):832-6.

34. Navaneethan U, Kemmer N, Neff GW. Predicting the probable outcome of treatment in HCV patients. Therap Adv Gastroenterol. 2009 Sep;2(5):287302.

35. Fargion S, Fracanzani AL, Valenti L. Treatment choices for people infected with HCV. J Antimicrob Chemother. 2004 May;53(5):708-12.

36. Yuan HJ, Lee WM. Nonresponse to treatment for hepatitis C: current management strategies. Drugs. 2008;68(1):27-42.

37. Davis GL. Monitoring of viral levels during therapy of hepatitis C. Hepatology. 2002 Nov;36(5 Suppl 1):S145-51.

38. Mihm U, Herrmann E, Sarrazin C, Zeuzem S. Review article: predicting response in hepatitis C virus therapy. Aliment Pharmacol Ther. 2006 Apr 15;23(8):1043-54.

39. Wright TL. Treatment of patients with hepatitis C and cirrhosis. Hepatology. 2002 Nov;36(5 Suppl 1):S185-94.

40. Everson GT, Hoefs JC, Seeff LB, Bonkovsky HL, Naishadham D, Shiffman ML, et al.; HALT-C Trial Group. Impact of disease severity on outcome of antiviral therapy for chronic hepatitis $\mathrm{C}$ : Lessons from the HALT-C trial. Hepatology. 2006 Dec;44(6):1675-84.

41. Ferenci P. Predictors of response to therapy for chronic hepatitis C. Semin Liver Dis. 2004;24 Suppl 2:25-31.

42. Narciso-Schiavon JL, Schiavon Lde L, Carvalho-Filho RJ, Sampaio JP, Batah PN, Barbosa DV, et al. Gender influence on treatment of chronic hepatitis C genotype 1. Rev Soc Bras Med Trop. 2010 MayJun;43(3):217-23

43. Reddy KR, Messinger D, Popescu M, Hadziyannis SJ. Peginterferon alpha-2a (40 kDa) and ribavirin: comparable rates of sustained virological response in sub-sets of older and younger HCV genotype 1 patients. J Viral Hepat. 2009 Oct;16(10):724-31.

44. McHutchison JG, Bacon BR. Chronic hepatitis C: an age wave of disease burden. Am J Manag Care. 2005 Oct;11(10 Suppl):S286-95; quiz S30711 .

45. Kuboki M, Iino S, Okuno T, Omata M, Kiyosawa K, Kumada H, et al. Peginterferon alpha-2a $(40 \mathrm{KD})$ plus ribavirin for the treatment of chronic hepatitis C in Japanese patients. J Gastroenterol Hepatol. 2007 May;22(5):645-52. Erratum in: J Gastroenterol Hepatol. 2007 May;22(5):768.

46. Fried MW. Side effects of therapy of hepatitis $\mathrm{C}$ and their management. Hepatology. 2002 Nov;36(5 Suppl 1):S237-44. 
47. Arase Y, Suzuki F, Suzuki Y, Akuta N, Kawamura Y, Kobayashi M, et al. Side effects of combination therapy of peginterferon and ribavirin for chronic hepatitis-C. Intern Med. 2007;46(22):1827-32.

48. Rodriguez-Torres M, Jeffers LJ, Sheikh MY, Rossaro L, Ankoma-Sey V, Hamzeh FM, et al.; Latino Study Group. Peginterferon alfa-2a and ribavirin in Latino and non-Latino whites with hepatitis C. N Engl J Med. 2009 Jan 15;360(3):257-67. Erratum in: N Engl J Med. 2010 Dec $16 ; 363(25): 2474$
49. Inoue Y, Hiramatsu N, Oze T, Yakushijin T, Mochizuki K, Hagiwara H, et al. Factors affecting efficacy in patients with genotype 2 chronic hepatitis $\mathrm{C}$ treated by pegylated interferon alpha- $2 \mathrm{~b}$ and ribavirin: reducing drug doses has no impact on rapid and sustained virological responses. J Viral Hepat. 2010 May;17(5):336-44.

Received July 8, 2011 Accepted in revised form January 18, 2012 